\title{
Early start to suicide prevention: Children's programme shows promising results
}

By Chris Bale

\author{
Zippy's Friends is a programme that teaches young children to cope with \\ difficulties. Evaluation studies of pilot programmes in Denmark and \\ Lithuania have shown excellent results and Zippy's Friends is now being \\ made available internationally. Voksne for Barn is planning to launch the \\ programme in Norway.
}

\section{Cries for help}

Telephone hel pline services are an integral part of suicide prevention strategies in many countries, with trained volunteers listening to people who are suicidal. The callers tell many different stories in many different languages, but one cry for help recurs - 'I don't know what to do.' Life has dealt the caller a harsh blow and she or he feels unable to cope.

This sad real ity led an international group of suicidologists to ponder the importance of teaching coping skills. They formulated a simple concept - if we can teach young children how to cope with difficulties, they should be better able to handle problems and crises in adolescence and adult life. From that concept, a programme called Zippy's F riends was born.

\section{Introducing Zippy}

There are plenty of programmes for children who have mental health problems or who are perceived as being especially vulnerable, but Zippy's F riends was designed to promote the emotional wellbeing of all young children. It was conceived as a suicide primary prevention programme but is perhaps more accurately described as a children's mental health promotion programme.

Zippy's F riends is suitable for six and seven year old children of all abilities. It teaches them how to cope with everyday-difficulties, to identify and talk about their feelings and to explore ways of dealing with them. It also en courages children to help other people with their problems. The programme is taught in schools and kindergartens by teachers who have been specially trained, and usually runs for 24 weeks, with one session per week.

The heart of the programme is six stories about a group of children and a stick insect called Zippy. O ver the course of 24 weeks, the stories track what happens to Zippy and his friends, dealing with issues that are familiar to young children
- friendship, communication, feeling lonely, bullying, dealing with change and Ioss, and making a new start. Each story is illustrated by brightly coloured pictures. A stick insect may seem an unlikely hero, but children love Zippy. $M$ any teachers make model stick insects for their classes and the children leave food for them every evening. 0 ne Lithuanian mother said: 'T he programme has transformed our family life. A II my children now listen properly to each other. I couldn't believe it when I found out Zippy was just a stick insect!'

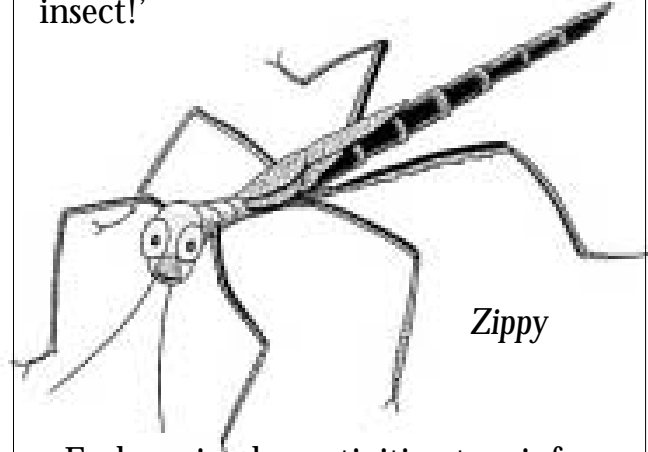

Each session has activities, to reinforce the messages of the stories. C hildren do a lot of role plays, draw pictures, work with puppets and even visit a graveyard. The emphasis is very much on encouraging them to explore, helping them to find their own solutions and expand their range of coping strategies, so that they have more options from which to choose.

$M$ any teachers who have taught the programme in Denmark and Lithuania have said that the programme's first and most obvious impact is that children become much better at resolving conflicts. $O$ ne $D$ anish teacher overheard a playground conversation in which a boy was complaining to two others about being bullied by them. The bullies then explained why they had been bullying him. 'I couldn't believe it,' said the teacher. 'T hree six year olds analysing bullying!' A Ithough Zippy's F riends is primarily intended to help young children, it also has value for teachers. $M$ any who have run the programme say that it has changed their perceptions of young children and improved classroom communication. O ne official from the W orld $\mathrm{H}$ ealth $\mathrm{O}$ rganisation even commented that the programme's greatest value is as a teacher training tool.

\section{Evaluation}

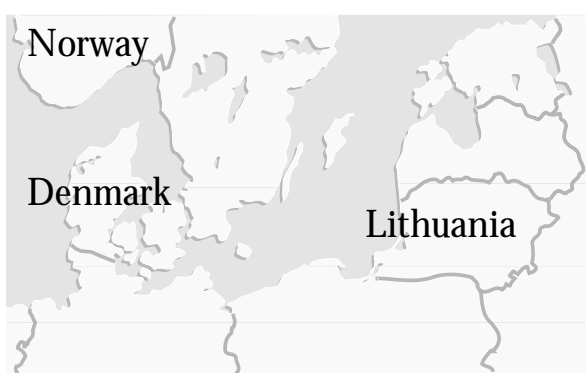

Zippy's F riends has been developed and tested in the contrasting settings of Denmark and Lithuania. More than 10,000 children have already completed the programme and the results have been carefully analysed in a series of evaluation studies. The first study, in Denmark in 1999, led by Prof Brian M ishara from the U niversity of Q uebec at M ontreal in C anada and A ssociate Professor M ette Ystgaard from the $U$ niversity of $O$ slo, recorded improvementsin the social skills of co-operation, empathy and self-control, but no effect on coping. In response, the programme was suspended for a year and the materials were comprehensively revised, with an extra module being added and more emphasis being placed on the development of coping skills.

The most recent major evaluation, again led by $M$ ishara and Y stgaard, looked at both the implementation and impact of the programme. The findings were based on data from experimental and control groups in both Denmark and Lithuania. The eval uators concluded that the programme had been implemented successfully. Teachers conducted the sessions with few problems, were satisfied with the training they had received and felt that the programme achieved its goals. 


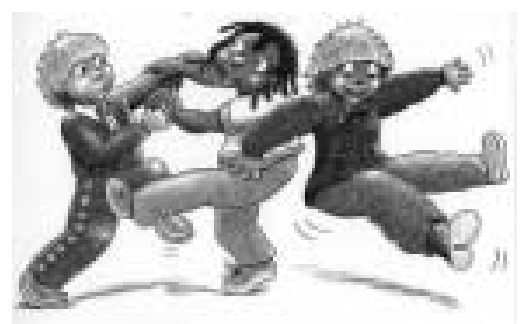

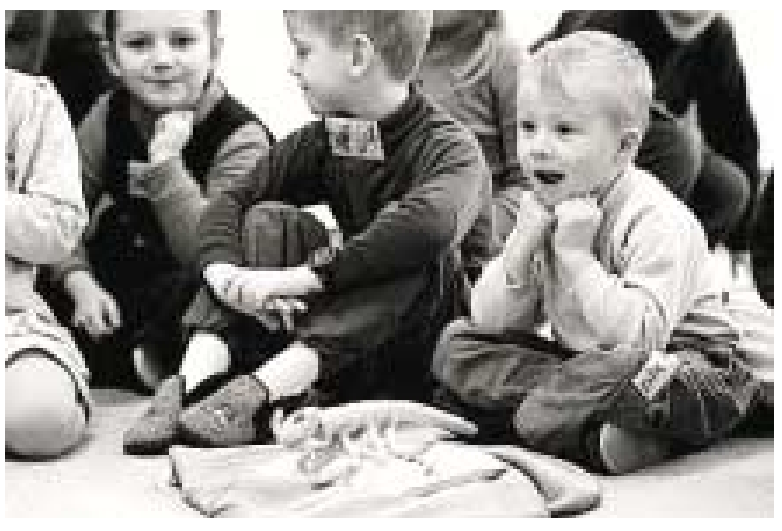

M ishara and Y stgaard concluded their study by saying: 'We don't know of another similar programme for young children that has been the object of such a detailed and rigorous evaluation process.' M ost programmes simply cannot afford such evaluation and credit is due to $\mathrm{G}$ laxoSmith Kline, which has funded the development and evaluation of Zippy's F riends for the past

They reported that children enjoyed the sessions - and some even commented that the programme had helped them to deal with problems in their own lives.

Looking at the programme's impact, the evaluators found that children in the experimental groups showed improvements in all the four key social skills that were tested - co-operation, self-control, assertion and empathy. There were clear improvements too in coping skills. In both D enmark and Lithuania there was an increase in positive coping strategies such as saying sorry, talking to a friend or telling the truth - and a decrease in negative strategies, such as getting mad, screaming or biting your nails. In Lithuania, the evaluators also looked at two problem behaviours - externalising and hyperactivity - and found that children in the programme showed significant decreases in both categories, compared to children in the control group.

The evaluators concluded that participation in Zippy's Friends results in significant improvements in coping, social skills and problem behaviours, and they were 'amazed' to find that these effects were equally evident in boys and girls.

Two more evaluation studies have also recently been completed in Lithuania, assessing the programme's effects on children. The first looked at children one year after they had completed Zippy's F riends and found that improvements recorded during the programme were maintained one year later. The second found that children who had participated in Zippy's F riends in their final year at kindergarten handled the transition to primary school more easily and more happily than children who had not joined the programme. six years in a particularly visionary example of corporate sponsorship.

\section{International expansion}

The whole aim of developing Zippy's F riends was to ben efit as many young children as possible, and the strong evaluation results mean that the programme can now be offered internationally.

It has been transferred from the nonprofit agency that developed it - Befrienders International - to a new one called Partnership for $C$ hildren. B efrien ders International ran a network of telephone helplines for suicidal people in more than 40 countries and Zippy's F riends was conceived as a primary suicide prevention programme, but it can now be more

\begin{tabular}{|c|c|}
\hline & MODULES \\
\hline $\begin{array}{l}\text { MODULE I } \\
\text { FEELINGS }\end{array}$ & $\begin{array}{l}\text { ST O RY } 1 \text { - Full of feelings } \\
\text { Session 1: Feeling sad - feeling happy } \\
\text { Session 2: Feeling angry or annoyed } \\
\text { Session 3: Feeling jealous } \\
\text { Session 4: Feeling nervous }\end{array}$ \\
\hline
\end{tabular}

\begin{tabular}{|c|c|}
\hline $\begin{array}{l}\text { COMMUNICATIONS } \\
\text { MODULE } 2\end{array}$ & $\begin{array}{l}\text { ST O RY } 2 \text { - Under the bedclothes } \\
\text { Session 1: Improving communication } \\
\text { Session 2: Listening } \\
\text { Session 3: W ho can help us? } \\
\text { Session 4: Saying what you want to say }\end{array}$ \\
\hline $\begin{array}{l}\text { M ODULE } 3 \\
\text { MAKING \& BREAKING } \\
\text { RELATIONSHIPS }\end{array}$ & $\begin{array}{l}\text { ST ORY } 3 \text { - Are you my friend? } \\
\text { Session 1: H ow to keep a friend } \\
\text { Session 2: Dealing with loneliness \& rejection } \\
\text { Session 3: H ow to resolve conflicts with friends } \\
\text { Session 4: How to make friends }\end{array}$ \\
\hline $\begin{array}{l}\text { RAg } \\
\text { MODULE } 4 \\
\text { CONFLICT RESOLUTION }\end{array}$ & $\begin{array}{l}\text { STORY } 4 \text { - Beating the bullies } \\
\text { Session 1: H ow to recognise good solutions } \\
\text { Session 2: Bullying } \\
\text { Session 3: Solving problems } \\
\text { Session 4: H elping others resolve conflicts }\end{array}$ \\
\hline $\begin{array}{l}\text { Pि } \\
\text { MODULE } 5 \\
\text { DEALING WITH } \\
\text { CHANGE AND LOSS }\end{array}$ & $\begin{array}{l}\text { ST ORY } 5 \text { - Saying goodbye } \\
\text { Session 1: C hange and loss are part of life } \\
\text { Session 2: Coping with death } \\
\text { Session 3: Visit to a graveyard } \\
\text { Session 4: Learning from change and loss }\end{array}$ \\
\hline 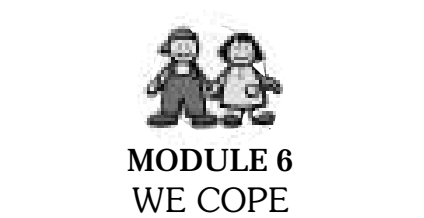 & $\begin{array}{l}\text { ST ORY } 6 \text { - We cope } \\
\text { Session 1: Different ways to cope } \\
\text { Session 2: H ow to help others } \\
\text { Session 3: A dapting to new situations } \\
\text { Session 4: C el ebrating together }\end{array}$ \\
\hline
\end{tabular}




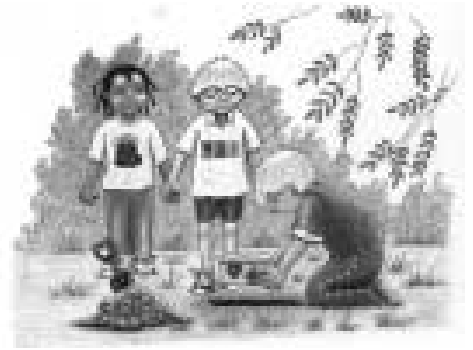

successfully promoted by an agency focusing exclusively on children and young people. Partnership for Children's mission is 'to help children and young people, throughout the world, develop skills which will enhance their present and future emotional wellbeing.'

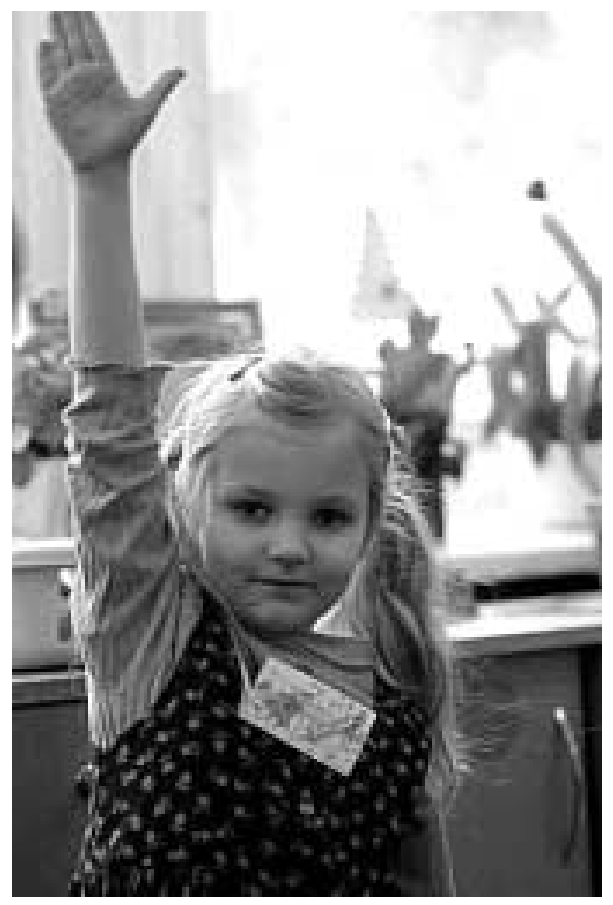

Although it has so far been run only in Denmark and Lithuania, Zippy's F riends was designed from the outset to be generic, suitable for use in different countries and cultures. Partnership for Children does not run the programme itself, pre-

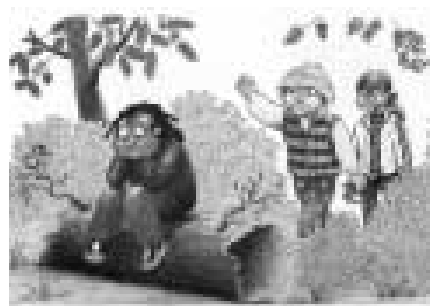

ferring to work through strong local partner agencies, and it will be interesting to see just how transferable the programme is. Its key principles are not negotiable, but adjustments or additions may be needed to make the programme suitable for a particular country or culture.

More than 7,000 children will complete the programme in Denmark and Lithuania this year. It will begin in England and India in September, and will be launched in Brazil in March 2004. A feasibility study on running the programme in Estonia has been completed, with positive results, and a similar study is ongoing in Poland. Discussions continue with Voksne for Barn, which is keen to run Zippy's F riends in Norway. More than 20 other countries have also shown interest in the programme.

Zippy's F riends tackles many issues that are directly relevant to young children, and different authorities are attracted to the programme for different reasons. For example, the Ministry of Education and Science in Lithuania believes the programme can help to combat drug and alcohol abuse among young people, while a partner agency in India thinks it will help to promote inter-ethnic tolerance. The agency that will run the programme in Brazil hopes that it will promote resilience in young people, while discussions in Australia are centred on the programme's value in reducing the number of youth suicides.

\section{Conclusion}

Evaluating the effectiveness of Zippy's Friends as a suicide prevention programme would require an impossibly ambitious, lifelong longitudinal study. However, there is now strong evidence that the programme helps young children to develop more coping skills and to both offer and receive help in difficult times. It also seems that these improvements are maintained one year on, and a further study is planned in Lithuania to evaluate the impact after five years. At the very least, Zippy's F riends can be said to improve the emotional wellbeing of young children. Hopefully, this will lead to fewer people feeling the need to end their own lives.

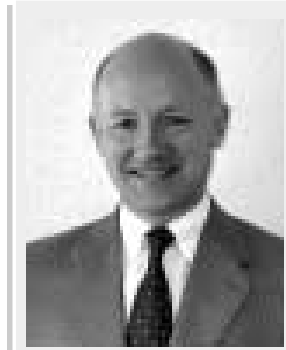

Chris B ale trained and worked as a print and television journalist before transferring to the nonprofit sector. He lived and worked in Asia for 20 years and was Director of Oxfam Hong Kong, an international development agency. In 1998,

he returned to his native Britain as Director of Befrienders International, a global network of suicide prevention hotlines. He joined Partnership for Children as its first Director in January 2002.

\section{Internett:}

www.partnershipforchildren.org.uk www.vfb.no (Voksne for barn)

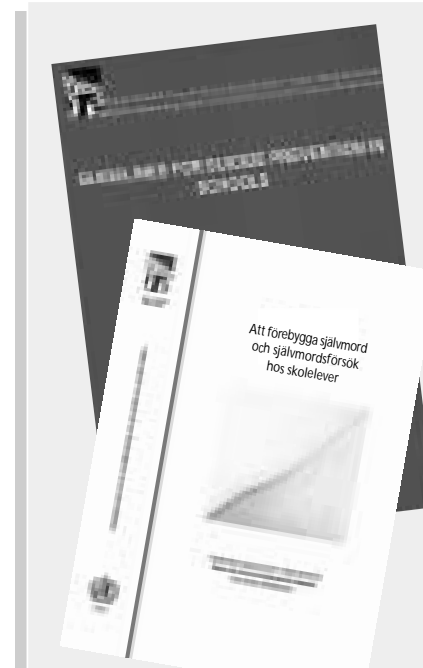

Wasserman, Danuta / Naboni, Véronique:

$\mathrm{G}$ uidelines for suicide prevention in schools. Stockholm: $\mathbf{N}$ ationellt centrum för suicidforskning och prevention av psykisk ohälsa (NASP), 2001 (rapport 2001, nr. 1) - 97 s.

Kan lastes ned fra http://www.ki.se/suicid/ rapporter/GuidelinesWHO.pdf

Nærmere informasjon:

http://www.ki.se/suicid/rapporter_guidelines_ schools.html

Rapporten kan bestilles via e-post fra NASP, pris kr. $100+$ eksp.:

Suicid.forskning@ipm.ki.se
NASP er Verdens helseorganisasjons samarbeidspartner for selvmordsforebygging, og har etter oppdrag fra WHO utarbeidet den omtalte rapporten. WHO har på grunnlag av den utgitt st $\varnothing$ ttemateriell til lærere og annet skolepersonale for å forebygge selvmord og selvmordsfors $\varnothing \mathrm{k}$ blant skoleelever over hele verden:

http://www.who.int/health_topics/suicide/en/ Dette skolemateriellet er også tilpasset svensk skole og utgitt på svensk: A tt förebygga självmord och självmordsförsök hos skolelever.

http://www.ki.se/suicid/nyhetsbrev/ who_stodmaterial_030528.pdf 